\title{
WPŁYW WYCHYLENIA BUDYNKU NA WYTĘŻENIE KONSTRUKCJI W WARUNKACH EKSPLOATACJI GÓRNICZEJ
}

\author{
Leszek Słowik ${ }^{\bowtie}$ \\ Instytut Techniki Budowlanej, Warszawa
}

\begin{abstract}
STRESZCZENIE
Jednym ze skutków podziemnej eksploatacji górniczej jest nachylenie powierzchni terenu powodujące przejściowe, a także - w określonych warunkach górniczo-geologicznych - trwałe wychylenie budynków z pionu. W artykule omówiony został aspekt statyczno-wytrzymałościowy wychylenia budynku wielokondygnacyjnego, spowodowanego podziemną eksploatacją górniczą. Wychylenie budynku z pionu powoduje pojawienie się dodatkowego poziomego obciążenia konstrukcji od ciężaru budynku. Wpływ poziomych sił na konstrukcję budynku jest szczególnie niekorzystny w przypadku obiektów o wysoko położonym środku ciężkości. W pracy przytoczono przykład symulacji numerycznej, której celem było określenie wytężenia konstrukcji wychylonego budynku. Ostatecznie podane zostały rezultaty przeprowadzonej analizy oraz wynikające z nich wnioski.
\end{abstract}

Słowa kluczowe: eksploatacja górnicza, wychylenie budynku, modelowanie konstrukcji

\section{WSTĘP}

Podziemna eksploatacja górnicza powoduje powstanie na powierzchni deformacji w postaci niecki górniczej, której jednym ze wskaźników jest nachylenie terenu (T). Niecka górnicza może mieć charakter statyczny bądź dynamiczny, a wychylenia budynków $\left(T_{b}\right)$ w obszarze jej oddziaływania mają postać przejściową (budynki 3 i 4 ) lub trwałą (budynki 1 i 2) - rysunek 1 (Kawulok, 2015).

Zgodnie z przedstawionymi w pracy Kawuloka (2015) obserwacjami, wychylenie budynku powodowane robotami górniczymi prowadzonymi w obrębie pojedynczej parceli eksploatacyjnej wynosi zazwyczaj od kilku do kilkunastu promili. Znaczne wartości wychylenia, wynoszące kilkadziesiąt promili, związane są przeważnie $\mathrm{z}$ deformacjami nieciągłymi zlokalizowanymi pod budynkiem, o charakterze stopnia terenowego lub uskoku. Nadmierne wychylenie budynku może wystąpić również w sytuacji, kiedy obiekt znajdzie się nad krawędzią eksploatacji kilku parceli (rys. 2).

Wychylenie budynków z pionu $\left(T_{b}\right)$ jest szczególnie niekorzystne dla obiektów smukłych, o wysoko położonym środku ciężkości, na co wskazują badania opisane w pracy Gubrynowicza (1978). Głównie w tego typu obiektach, przy znacznym wychyleniu, może dojść do zagrożenia stateczności i wytrzymałości konstrukcji. Przykładem trwale wychylonego budynku z pionu, o wysoko położonym środku ciężkości, jest jedenastokondygnacyjny segment wielorodzinny, wzniesiony w ,ślizgu”, który został poddany analizie z uwagi na warunki zachowania bezpieczeństwa wytężonych elementów konstrukcji.

Wychylenie budynku z pionu jest zjawiskiem, któremu pod względem statyczno-wytrzymałościowym trudno przeciwdziałać. Czynniki takie, jak: ciężar własny konstrukcji, obciążenie użytkowe, parcie wiatru oraz

\footnotetext{
『I.slowik@itb.pl
} 


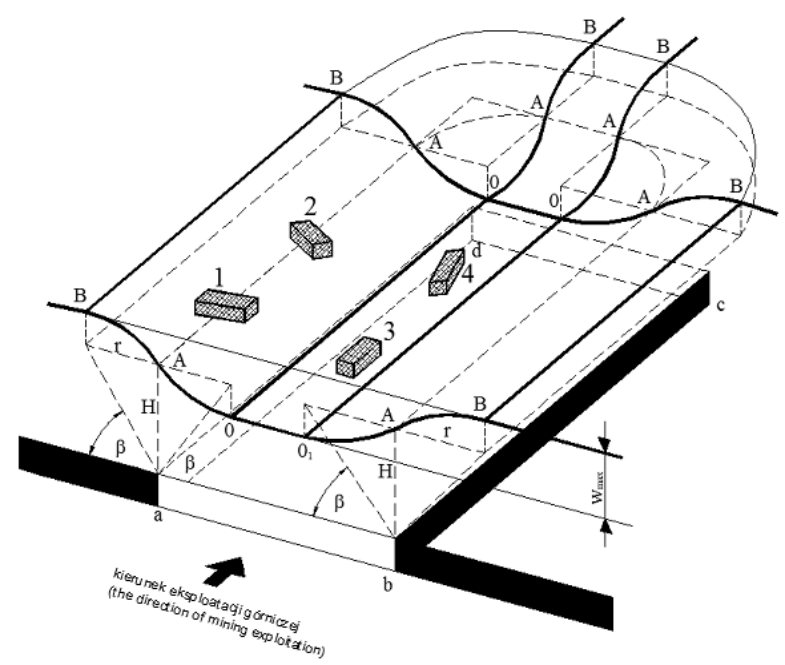

Rys. 1. Możliwe usytuowanie obiektu względem krawędzi eksploatacji (Kawulok, 2015)

Fig. 1. Possible location of the object relative to the edge of the exploitation (Kawulok, 2015)

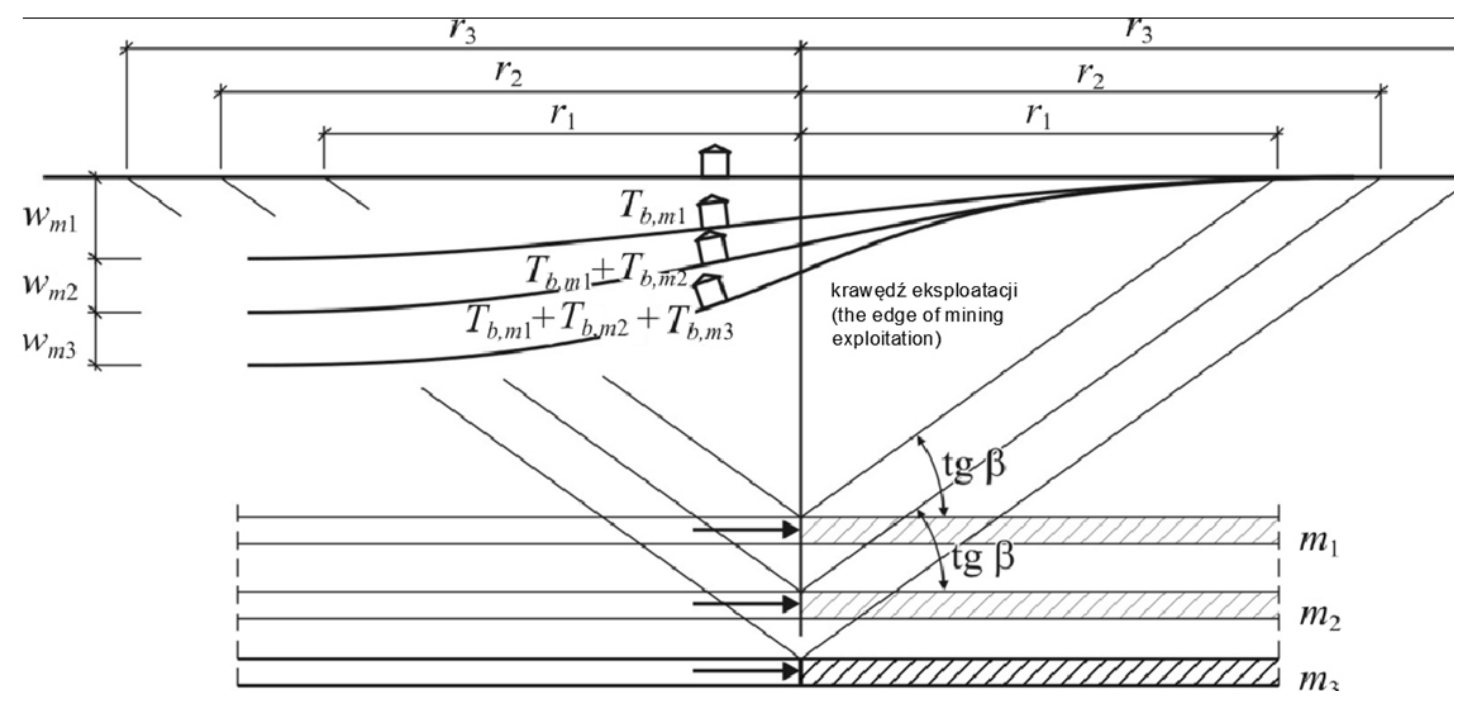

Rys. 2. Wychylenie budynku na krawędzi eksploatacji kilku pokładów: $\beta, r_{i}$ - kąt i promień zasięgu wpływów głównych; $w_{m i}, T_{b, m i}$ - obniżenie terenu i wychylenie obiektu od eksploatacji kolejnych pokładów (Kawulok, 2015)

Fig. 2. Deflection of the building at the edge of the exploitation of several decks: $\beta, r_{i}$ - angle and radius of the main influences; $w_{m i}, T_{b, m i}$ - lowering of the area and tilting of the object from the operation of subsequent decks (Kawulok, 2015)

powstanie dodatkowego układu sił związanego z wychyleniem budynku, mają wpływ na stan wytrzymałości i stateczności konstrukcji.

Celem pracy jest pokazanie, jakie elementy konstrukcji budynku w warunkach oddziaływania nachylenia terenu ulegają zwiększonemu wytężeniu. W artykule przedstawiono przykład analizy segmentu poddanego wpływowi istniejącego i prognozowanego wychylenia od pionu. Z wielu względów przedstawiona w niniejszej pracy analiza ma charakter uproszczony. 
Artykuł powstał na podstawie pracy nr 1539/13/Z00 OSK (2013), której celem było określenie stanu bezpieczeństwa użytkowania budynków wielokondygnacyjnych, nadmiernie wychylonych z pionu.

\section{MATERIA I METODY}

\section{Opis konstrukcji}

Budynek jedenastokondygnacyjny wybudowany został od poziomu ław fundamentowych do konstrukcji dachu metodą ślizgową. Segment wzniesiono jako całkowicie podpiwniczony, o wymiarach gabarytowych rzutu poziomego wynoszących 17,40 × 19,70 m (rys. 3).

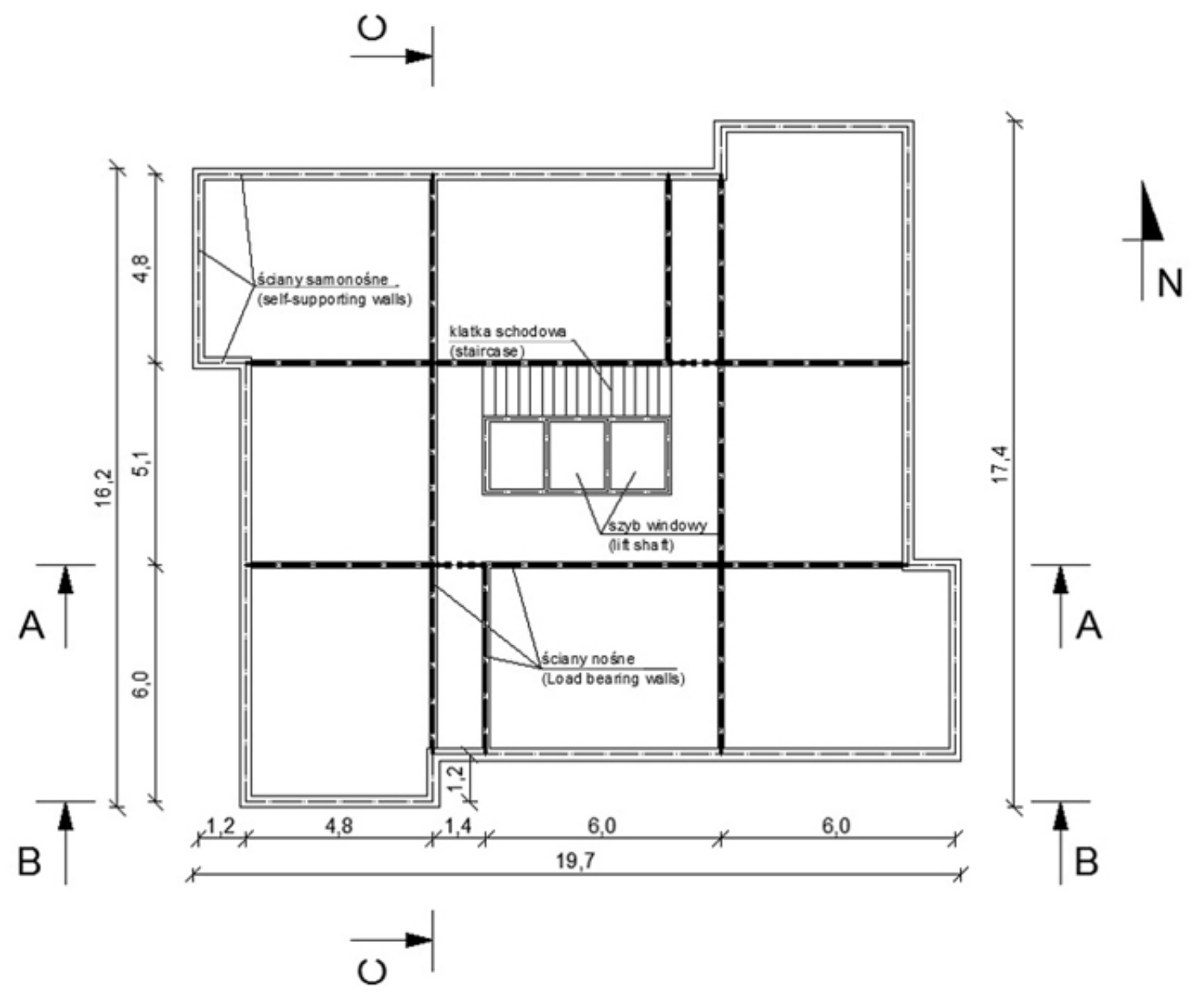

Rys. 3. Schemat rzutu kondygnacji powtarzalnej analizowanego budynku wzniesionego metodą ślizgową (Praca..., 2013)

Fig. 3. Diagram of the repeat floor plan of the analyzed building erected by the sliding method (Praca..., 2013)

Wysokość segmentu mierzona od poziomu posadzki na parterze do stropu nad ostatnią kondygnacją wynosi 29,64 m, przy wysokości kondygnacji 2,70 m. Zasadniczy ustrój konstrukcyjny stanowią ściany wewnętrzne rozmieszczone krzyżowo. Posadowienie budynku zrealizowane zostało jako bezpośrednie przez wykonanie żelbetowych ław fundamentowych, stanowiących sztywny ruszt. Ławy o stałej szerokości 1,2 m i wysokości 0,4 m, zgodnie z dokumentacją projektową (MIASTOPROJEKT - KATOWICE, 1967), zaprojektowano i wy- 
konano przy założeniu dopuszczalnego nacisku na grunt na poziomie $q_{\max }=200 \mathrm{kPa}\left(2 \mathrm{kG} \cdot \mathrm{cm}^{-2}\right)$ oraz wpływów deformacyjnych właściwych dla III kategorii terenu górniczego (Kwiatek, Dubiński, Frolik, Gil-Kleczeńska, Jędrzejec, Kowalski, ... i Zawora, 2000).

Przyjęte rozwiązania konstrukcyjne, o których mowa dalej, stanowią o zabezpieczeniu segmentu przed negatywnymi skutkami oddziaływania eksploatacji górniczej. Żelbetowe ławy fundamentowe przejmują siły wynikające z poziomych odkształceń gruntu. Tarcze stropowe wszystkich kondygnacji o konstrukcji płytowej krzyżowo zbrojonej, grubości $12 \mathrm{~cm}$, zostały zmonolityzowane ze ścianami nośnymi budynku. Rozwiązanie to stanowi poziome skotwienie budynku, które wraz z kondygnacją piwniczną, stanowiącą sztywną monolityczną skrzynię żelbetową, odpowiada za przejmowanie momentów zginających i sił poprzecznych, będących efektem oddziaływania na konstrukcję budynku krzywizny terenu (Kawulok, 1983). Z kolei krzyżowo usytuowane ściany nośne zmonolityzowane $\mathrm{w}$ wieńcach $\mathrm{z}$ tarczami stropowymi mają za zadanie przejmować obciążenia siła poziomą od ciężaru konstrukcji budynku, która powstaje przy jego wychyleniu od pionu. Ściany ustroju nośnego wykonano jako żelbetowe, zewnętrzne o grubości $30 \mathrm{~cm}$ i wewnętrzne $-15 \mathrm{~cm}$.

Pionowa komunikacja wewnętrzna w budynku zrealizowana została przez wykonanie $\mathrm{w}$ centralnej części rzutu poziomego szybu windowego, ograniczonego ścianami żelbetowymi grubości $15 \mathrm{~cm}$, i wewnętrznych żelbetowych schodów płytowych biegnących wokół szybu wind. Zadaszenie stanowi strop ostatniej kondygnacji z ociepleniem, kryty papą, ze spadkiem połaci do wnętrza budynku.

Stan techniczny budynku jest zadowalający, a zinwentaryzowane uszkodzenia mają charakter zarysowań, głównie skurczowych, związanych z technologią budowy segmentu. Podkreślić należy, iż nie są to uszkodzenia konstrukcyjne, a ich przebieg, miejsce występowania i intensywność nie zagraża bezpieczeństwu konstrukcji analizowanego budynku.

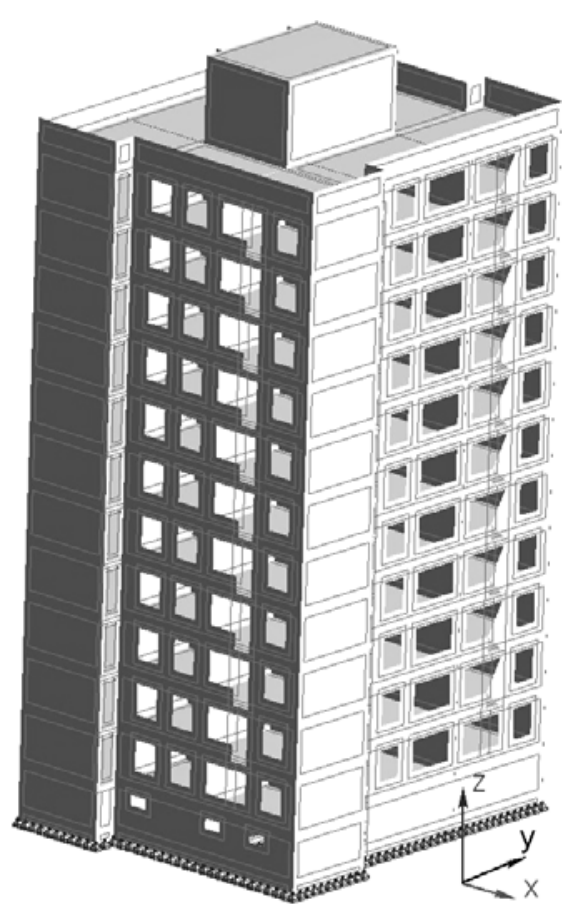

Rys. 4. Przestrzenny model analizowanego budynków (Praca..., 2013)

Fig. 4. Spatial model of analyzed building (Praca..., 2013)
Wychylenie od pionu, mierzone po pionowych krawędziach budynku, wynosi $T_{b \max }=29,3 \%$ (Praca..., 2013). Prognozowane wpływy od projektowanej do 2020 roku eksploatacji górniczej mogą spowodować przyrost wychylenia segmentu $\Delta T_{b, \text { prog }}=0,7 \%$.

\section{Symulacja obliczeniowa konstrukcji z uwagi na wychylenie}

Założenia wstępne. Wykonując przybliżoną analizę obliczeniową, parametry geometryczne modelu ustalono na podstawie projektu konstrukcji budynku (MIASTOPROJEKT - KATOWICE, 1967), odwzorowując w pełni bryłę budynku. Zbudowano numeryczny model przestrzenny $M E S$, wykorzystując program Robot Autodesk Structural Analisys (rys. 4).

W zbudowanym modelu obliczeniowym uwzględniono wszystkie ściany nośne, samonośne oraz stropy, przyjmując je, za MIASTOPROJEKTEM - KATOWICE (1967), jako elementy monolitycznie związane. Do budowy modelu MES wykorzystano powłokowe, czworokątne elementy skończone o wymiarach boków $0,25 \times 0,25 \mathrm{~m}$.

Podparcie modelu zrealizowano za pomocą podpór uniemożliwiających przesuw w pionie i poziomie, przyłożonych wzdłuż wszystkich ław fundamentowych, pomijając tym samym wpływ współpracy konstrukcji z podłożem.

W obliczeniach uwzględniono następujące obciążenia: użytkowe, wiatrem, śniegiem, pochodzącym od wychylenia obiektu od pionu, a także ciężarem własnym konstrukcji. Obciążenia oraz parametry 
Słowik, L. (2017). Wpływ wychylenia budynku na wytężenie konstrukcji w warunkach eksploatacji górniczej. Acta Sci. Pol. Architectura, 16 (3), 155-164. doi: 10.22630/ASPA.2017.16.3.16.

materiałowe ustalono na podstawie norm obowiązujących w okresie wzniesienia budynku. Analizę wykonano dla obciążeń obliczeniowych.

Parametry materiałowe ścian zewnętrznych i wewnętrznych wykonanych z betonu $R_{w} 90$ i $R_{w} 200$, analizowanych w pracy, ustalono na podstawie PN-56/B-03260 i podano w tabeli 1.

Tabela 1. Parametry przyjętych do obliczeń betonów marki $R_{w} 200$ i $R_{w} 90$

Table 1. Parameters of the concrete brands adopted for the calculation $R_{w} 200$ i $R_{w} 90$

\begin{tabular}{lcc}
\hline Parametr - Parameter & \multicolumn{2}{c}{ Beton marki-Concrete brand } \\
\cline { 2 - 2 } $\begin{array}{l}\text { Wytrzymałość gwarantowana na próbce sześciennej o boku } 15 \mathrm{~cm}, R_{b}^{G} \\
\text { Guaranteed strength on the cubic sample with a side of } 15 \mathrm{~cm}, R_{b}^{G}\end{array}$ & $R_{w} 200$ & $R_{w} 90$ \\
\hline $\begin{array}{l}\text { Wytrzymałość obliczeniowa na ściskanie osiowe, } R_{s}\left(f_{c d}^{\mathrm{a}}\right) \\
\text { Computational strength on axial compression, } R_{s}\left(f_{c d}^{\mathrm{a}}\right)\end{array}$ & $18,0 \mathrm{MPa}$ & $8,0 \mathrm{MPa}$ \\
\hline $\begin{array}{l}\text { Wytrzymałość obliczeniowa na rozciąganie osiowe, } R_{r} \\
\text { Computational strength on axial tensile, } R_{r}\end{array}$ & $14,5 \mathrm{MPa}$ & $7,2 \mathrm{MPa}$ \\
\hline Współczynnik sprężystości, $E$ - Coefficient of elasticity, $E$ & $1,75 \mathrm{MPa}$ & $1,0 \mathrm{MPa}$ \\
\hline Ciężar objętościowy, $\gamma$ - Volume weight, $\gamma$ & $29,0 \mathrm{GPa}$ & $18,0 \mathrm{GPa}$ \\
\hline
\end{tabular}

${ }^{a}$ Obliczeniowa wartość betonu na ściskanie określona na podstawie PN-B-03264.

Computational value of concrete for compression determined on the basis of PN-B-03264.

${ }^{\mathrm{b}}$ Ciężar objętościowy dla betonu żwirowego - Volume weight for gravel concrete.

${ }^{\mathrm{c}}$ Ciężar objętościowy dla pumeksopyłobetonu - Volume weight for concrete with pumice powder.

Obciążenie związane z wychyleniem budynku. Wpływ wychylenia budynku określony został dla wychylenia istniejącego, wynoszącego $T_{b}=29,3 \%$, oraz dla wychylenia, którego przyrost $\mathrm{w}$ wyniku projektowanej eksploatacji górniczej będzie zgodny z obecnym wychyleniem segmentu i zwiększy się w stosunku do stanu istniejącego o $\Delta T_{b \text { prog }}=0,7 \%$. Ostatecznie dla eksploatacji projektowanej wychylenie budynku wyniesie $T_{b, \text { proj }}=\gamma_{T} \cdot T_{b}+$ $+\gamma_{T} \cdot \Delta T_{b, \mathrm{prog}}=1,1 \cdot 29,3+1,5 \cdot 0,7=33,28 \%$.

Obciążenie konstrukcji wynikające $\mathrm{z}$ wychylenia zostało zdefiniowane w modelu obliczeniowym przez obrót płaszczyzny poziomej OXY wokół osi OX i OY (rys. 4) o kąt wynikający z wychylenia pomierzonego w warunkach in situ.

Omawiana powyżej metodologia wykorzystywana jest głównie w analizach o charakterze inżynierskim i pozwala na oszacowanie po stronie bezpiecznej możliwych zmian wytężenia konstrukcji wychylonej, bez uwzględnienia jej współpracy z podłożem. Prace naukowe z zakresu analiz wpływu nachylenia terenu na wychylenie budynku dotyczą symulacji współpracy obiektu budowlanego z deformującym się podłożem górniczym. Kompendium wiedzy w tym zakresie stanowią prace Fedorowicz (2006) i Fedorowicza (2008). Przykład prognozowania wychylenia budynku z pionu, powodowanego nachyleniem terenu w warunkach eksploatacji górniczej, podany został również przez Słowika (2016).

\section{WYNIKI I DYSKUSJA}

\section{Wyniki obliczeń}

Wyniki obliczeń dla dwóch sytuacji obliczeniowych, tj. modelu budynku przed wychyleniem oraz uwzględniającego dodatkowe obciążenie od istniejącego i prognozowanego wychylenia segmentu, podano na rysunkach $5-10$. 


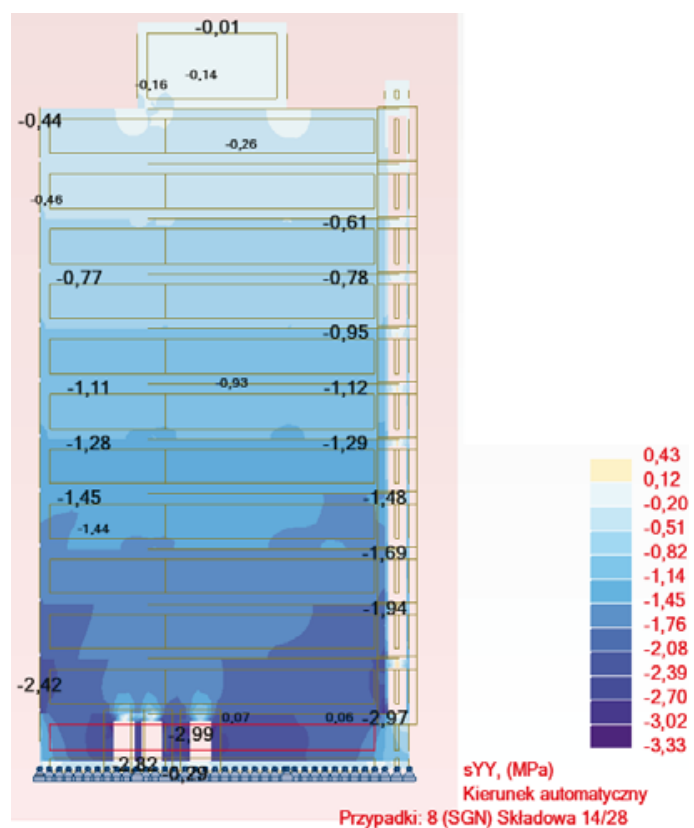

Rys. 5. Mapa naprężeń pionowych $\left(\sigma_{v y}\right)$ dla południowej wewnętrznej ściany budynku (A-A, rys. 3) przed jego wychyleniem

Fig. 5. Map of vertical stress $\left(\sigma_{y y}\right)$ for the southern inner wall of the building (A-A, Fig. 3) and vertical variant

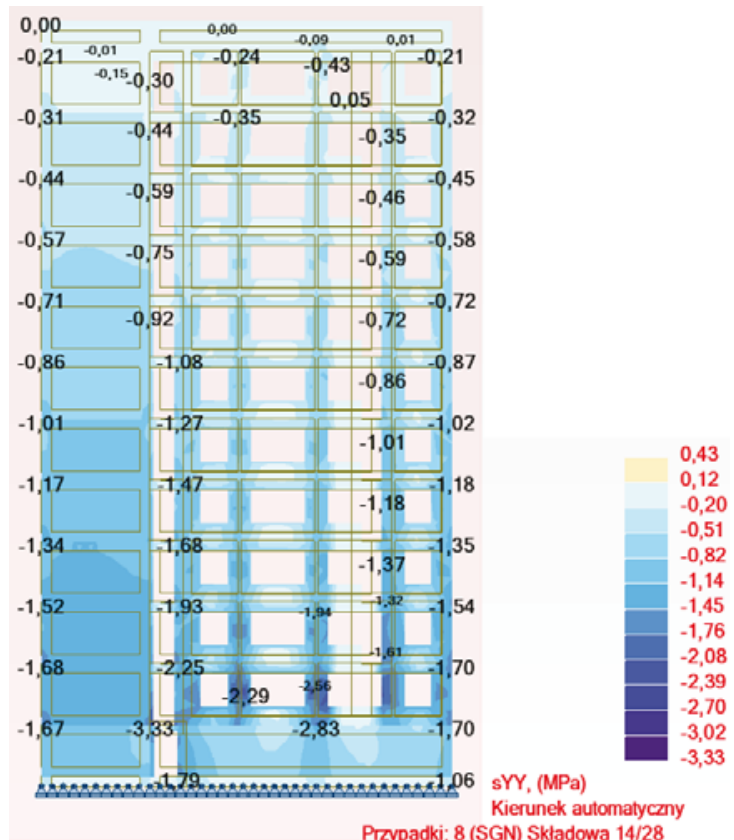

Rys. 7. Mapa naprężeń pionowych $\left(\sigma_{y y}\right)$ dla południowej zewnętrznej ściany budynku (B-B, rys. 3) przed jego wychyleniem

Fig. 7. Map of vertical stress $\left(\sigma_{y y}\right)$ for the southern outer wall of the building (B-B, Fig. 3) and vertical variant

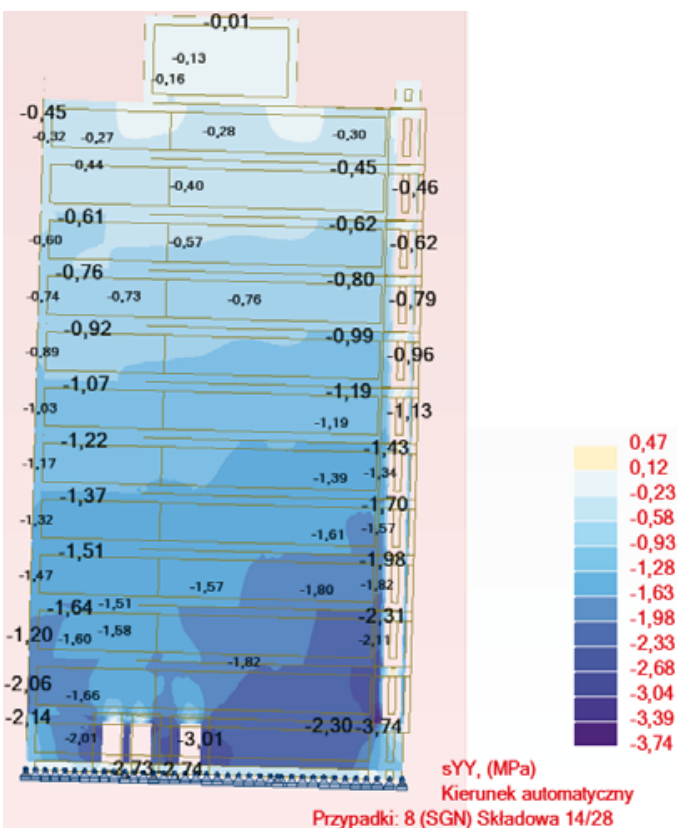

Rys. 6. Mapa naprężeń pionowych $\left(\sigma_{y y}\right)$ dla południowej wewnętrznej ściany budynku (A-A, rys. 3) wychylonego

Fig. 6. Map of vertical stress $\left(\sigma_{y y}\right)$ for the southern inner wall of the building (A-A, Fig. 3) and tilted variant

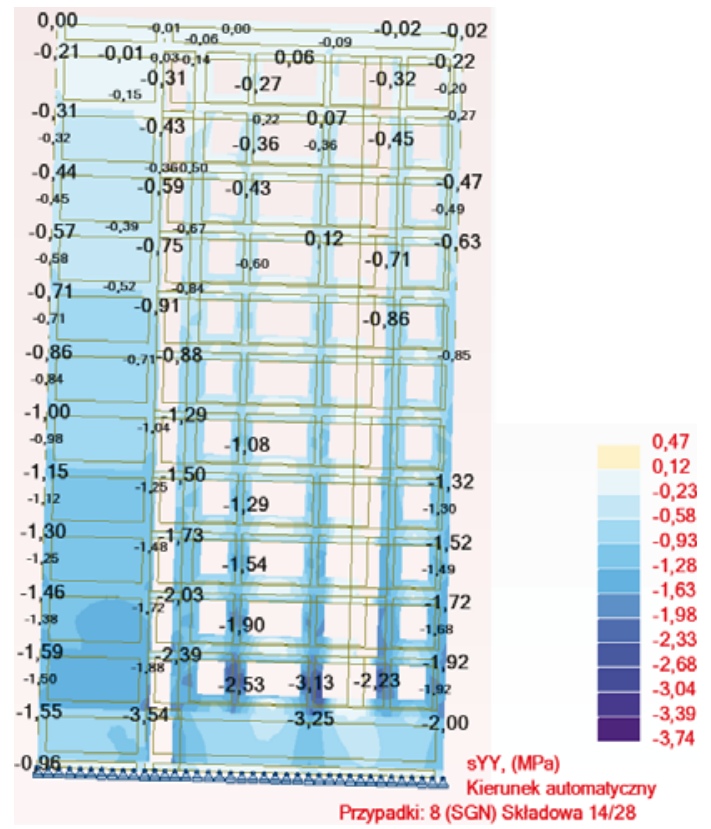

Rys. 8. Mapa naprężeń pionowych $\left(\sigma_{y y}\right)$ dla południowej zewnętrznej ściany budynku (B-B, rys. 3) wychylonego

Fig. 8. Map of vertical stress $\left(\sigma_{y y}\right)$ for the southern outer wall of the building (B-B, Fig. 3) and tilted variant 


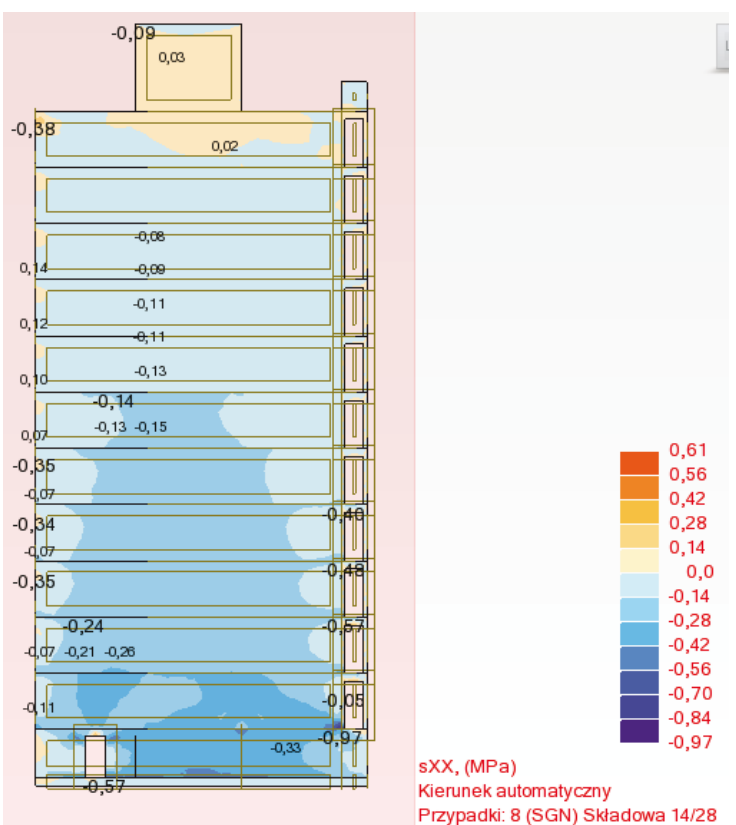

Rys. 9. Mapa naprężeń poziomych $\left(\sigma_{x x}\right)$ dla zachodniej wewnętrznej ściany budynku $(\mathrm{C}-\mathrm{C}$, rys. 3$)$ przed wychyleniem

Fig. 9. Map of vertical stress $\left(\sigma_{x x}\right)$ for the western inner wall of the building (C-C, Fig. 3) and vertical variant

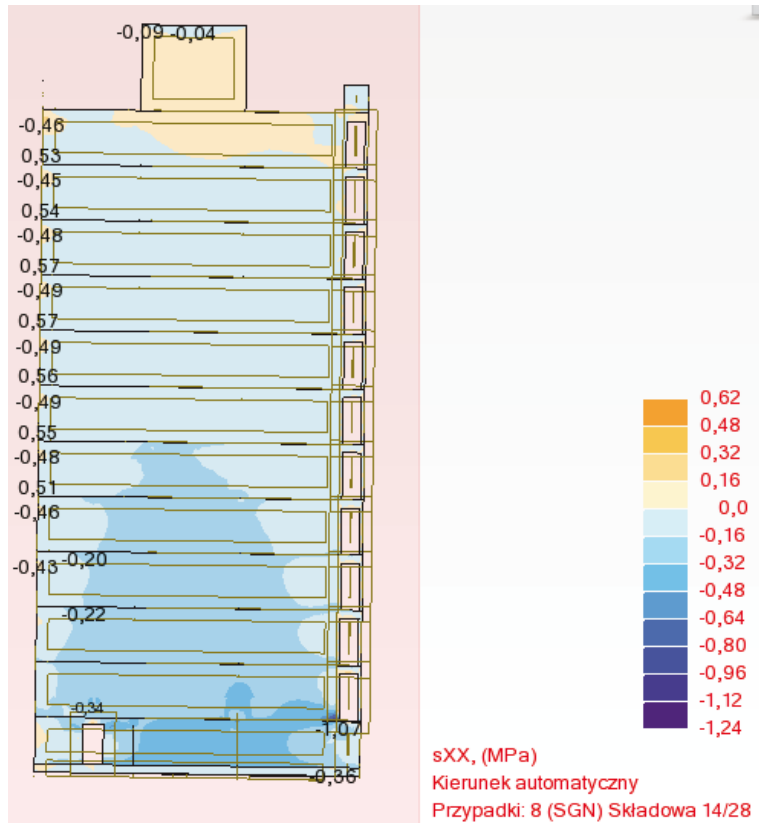

Rys. 10. Mapa naprężeń poziomych $\left(\sigma_{x x}\right)$ dla zachodniej wewnętrznej ściany budynku (C-C, rys. 3) wychylonego

Fig. 10. Map of vertical stress $\left(\sigma_{x x}\right)$ for the western inner wall of the building (C-C, Fig. 3) and tilted variant

Otrzymane wyniki obliczeń pokazują relatywnie znaczący z punktu widzenia wytężenia konstrukcji wzrost ekstremalnych naprężeń pionowych w budynku wychylonym w stosunku do segmentu przed wychyleniem. Przykładowo w ścianie wewnętrznej A-A (rys. 5 i 6) naprężenia pionowe zmieniają się z wartości 2,97 MPa do wartości 3,74 MPa, a w ścianie zewnętrznej B-B (rys. 7 i 8) - z wartości 3,33 MPa do wartości 3,54 MPa. W wyniku wychylenia budynku otrzymano maksymalne zmiany naprężenia $\left(\sigma_{v y}\right)$ rzędu około $25 \%$. Naprężenia te występują w narożach wklęsłych ścian zewnętrznych w poziomie stropu nad piwnicą. Można też zauważyć nieznaczne zwiększenie maksymalnych lokalnych naprężeń rozciągających z 0,43 do 0,47 MPa (ok. 9\%), które wystąpiły w rejonie połączenia stropu nad kondygnacją parteru ze ścianą zewnętrzną. Różnica ta wynika prawdopodobnie z zaburzeń siatkowania przy krawędziach paneli.

\section{Uwagi ogólne}

Podstawowym wymaganiem stawianym budynkom jest zapewnienie odpowiednich warunków użytkowych, a przede wszystkim zapewnienie bezpieczeństwa jego konstrukcji. W analizie obiektów na terenach górniczych należy uwzględniać obciążenie wynikające z wychylenia obiektu od pionu.

Wytężenie konstrukcji budynku określone zostało z uwzględnieniem oddziaływań pojawiających się w wyniku wychylenia dodatkowych sił poziomych, które wywołują dodatkowy stan naprężeń, głównie w ścianach betonowych, na wysokości wieńców stanowiących monolityczne połączenie pomiędzy ścianami i stropami. Najbardziej narażone jest złącze poziome na wysokości stropu nad piwnicą z uwagi na największe w tym miejscu naprężenia pionowe. 
Ostatecznie w ramach wykonanych obliczeń wykonane zostanie sprawdzenie, czy otrzymane w symulacji numerycznej maksymalne wartości sił nie przekraczają wartości dopuszczalnych.

\section{Analiza wytężenia konstrukcji}

Zgodnie z zaleceniami normy PN-B-03264:2002 nośność ścian betonowych określono wzorem:

$$
N_{R d}=\varphi \cdot f_{c d}^{*} \cdot b \cdot h
$$

gdzie: $N_{R d}-$ nośność obliczanej ściany betonowej,

$\varphi=0,6$ dla $e_{0} / h=0,2$, gdzie $\varphi$ - współczynnik ustalony według tablicy 10 normy,

$f_{c d}^{*}$ - wytrzymałość obliczeniowa na ściskanie betonu płyty ściennej; dla ściany wewnętrznej przy $R_{w} 200$ przyjęto $f_{c d}^{*}=14,5 \mathrm{MPa}$, a dla ściany zewnętrznej przy $R_{w} 90$ przyjęto $f_{c d}^{*}=7,2 \mathrm{MPa}$,

$b$ - szerokość analizowanego elementu, przyjęto $b=1,0 \mathrm{~m}$,

$h$ - grubość analizowanego elementu.

Spełnienie warunku nośności wymaga, aby:

$$
N_{R d}>N_{S d}
$$

gdzie $N_{S d}$ - wartość siły określającej wytężenie konstrukcji ściany dla analizowanego przypadku obciążenia.

W ścianie wewnętrznej A-A (rys. 6), wykonanej z betonu marki $R_{w} 200$, otrzymano z rozwiązania modelu wartość naprężenia maksymalnego $\sigma_{w y n 1}=3,74 \mathrm{MPa}$. Zatem wartość siły określającej wytężenie ściany przy grubości przegrody $h=0,15 \mathrm{~m}$ można oszacować na poziomie:

$$
N_{S d}=\sigma_{w y n l} \cdot b \cdot h=3,74 \cdot 1 \cdot 0,15=0,561 \mathrm{MN}
$$

Nośność tej ściany wynosi natomiast:

$$
N_{R d}=\varphi \cdot f_{c d} \cdot b \cdot h=0,6 \cdot 14,5 \cdot 1 \cdot 0,15=1,305 \mathrm{MN}
$$

Zatem warunek nośności: $N_{R d}=1,305 \mathrm{MN}>N_{S d}=0,561 \mathrm{MN}$ - został spełniony.

Dla ściany zewnętrznej B-B (rys. 8), wykonanej z betonu marki $R_{w} 90$, z obliczeń uzyskano: $\sigma_{w y n 2}=3,54 \mathrm{MPa}$. Wartość siły wewnętrznej określonej dla ściany B-B, przy grubości $h=0,30 \mathrm{~m}$, wynosi:

$$
N_{S d}=\sigma_{w y n 2} \cdot b \cdot h=3,54 \cdot 1 \cdot 0,3=1,062 \mathrm{MN}
$$

Nośność tej ściany wynosi natomiast:

$$
N_{R d}=\varphi \cdot f_{c d} \cdot b \cdot h=0,6 \cdot 7,2 \cdot 1 \cdot 0,3=1,296 \mathrm{MN}
$$

Zatem również w tym przypadku warunek nośności: $N_{R d}=1,296 M N>N_{S d}=1,062 \mathrm{MN}-$ został spełniony.

Analiza wytężenia konstrukcji segmentu wychylonego od pionu wykazała, że siły w ścianach betonowych nie przekraczają ich nośności, w związku z czym są dopuszczalne i nie stanowią zagrożenia dla bezpieczeństwa konstrukcji. 


\section{PODSUMOWANIE}

Wychylenie budynku w warunkach oddziaływania wpływów podziemnej eksploatacji górniczej powoduje dodatkowe wytężenie elementów konstrukcji. W artykule przedstawiono przykład analizy segmentu, w którym ocenie poddane zostały ściany betonowe $\mathrm{w}$ zakresie oceny wzrostu naprężeń ściskających $\mathrm{w}$ miejscu największego wytężenia konstrukcji, czyli stropu nad piwnicą.

Z przeprowadzonej analizy wynika, że nośność ścian betonowych, narażonych na niekorzystne oddziaływanie wychylenia na budynek, została zachowana. Podkreślenia wymaga fakt, że w symulacji numerycznej przyjęto bardziej niekorzystne obliczeniowe wartości obciążeń, co jest założeniem dość bezpiecznym. Dodatkowo, z uwagi na brak odpowiednich danych analizowano jedynie nośność ścian betonowych. Ocenie nie zostały poddane zmonolityzowane $\mathrm{w}$ wieńcach połączenia ścian i stropów $\mathrm{z}$ uwagi na nieznajomość ilości zbrojenia. W miejscach tych, w warunkach in situ, nie stwierdzono jednak uszkodzeń, przez co uznać można otrzymane wyniki za wystarczające.

$\mathrm{Z}$ punktu widzenia warunków dalszego użytkowania budynku w omawianym przypadku decydujący jest aspekt użytkowy (Kawulok, 2000), czyli pogorszenie warunków użytkowych panujących w budynku wraz z jego wychyleniem z pionu. W instrukcji (Kwiatek i in., 2000) podane zostały stopnie uciążliwości użytkowania, które klasyfikują skutki oddziaływań górniczych w pogarszaniu się standardów użytkowania pomieszczeń. Jednym z tych parametrów jest wychylenie budynków z pionu $\left(T_{b}\right)$. W rozpatrywanym przypadku, przy wychyleniu analizowanego budynku o wartość $T_{b \text {,roj }}=32,28 \%$, stwierdzono duży stopień uciążliwości, co budynek kwalifikuje do rektyfikacji (Kwiatek, 1997).

\section{PIŚMIENNICTWO}

Fedorowicz, J. (2008). Zagadnienie kontaktowe budowla - podłoże gruntowe. Część II. Kryteria tworzenia i oceny modeli obliczeniowych układów konstrukcja budowlana - podłoże górnicze. Zeszyty Naukowe Politechniki Śląskiej, Budownictwo, 1805 (114).

Fedorowicz, L. (2006). Zagadnienia kontaktowe budowla - podłoże gruntowe. Część I. Kryteria modelowania i analiz podstawowych zagadnień kontaktowych konstrukcja budowlana - podłoże gruntowe. Zeszyty Naukowe Politechniki Śląskiej, Budownictwo, 1729 (107).

Gubrynowicz, A. (1978). Wychylenia z pionu obiektów budowlanych na tle nachyleń terenu powodowanych wpływami eksploatacji górniczej. W Problemy budownictwa na terenach górniczych. Warszawa: ITB.

Kawulok, M. (1983). Przybliżony rozkład sił wewnętrznych w budynkach wielkopłytowych na terenach górniczych. Inżynieria i Budownictwo, (4), 179-183.

Kawulok, M. (2000). Ocena właściwości użytkowych budynków z uwagi na oddziaływania górnicze. Warszawa: ITB.

Kawulok, M. (2015). Szkody górnicze w budownictwie. Warszawa: ITB.

Kwiatek, J. (1997). Ochrona obiektów budowlanych na terenach górniczych. Katowice: Główny Instytut Górnictwa.

Kwiatek, J., Dubiński, J., Frolik, A., Gil-Kleczeńska, B., Jędrzejec, E., Kowalski, A., ... i Zawora, J., (2000). Zasady oceny możliwości prowadzenia podziemnej eksploatacji górniczej z uwagi na ochronę obiektów budowlanych (Instrukcja nr 12). Katowice: Główny Instytut Górnictwa.

MIASTOPROJEKT - KATOWICE, (1967). Obliczenia statyczne budynku mieszkalnego 11-kond. typu S13-m, wykonanego w deskowaniach ślizgowych w Brynowie przy ul. Wincentego Pola nr 6.

PN-56/B-03260. Konstrukcje żelbetowe. Obliczenia statyczne i projektowanie.

PN-B-03264:2002. Konstrukcje betonowe, żelbetowe i sprężone. Obliczenia statyczne i projektowanie.

Praca nr 1539/13/Z00 OSK (2013). Ocena stanu bezpieczeństwa użytkowania wychylonych od pionu budynków mieszkalnych położonych przy ul. Ligockiej 2, 4, 4A, 6, ul. Brynowskiej 43, 45 i ul. Mikołowskiej 113 w Katowicach oraz pracy dźwigów osobowych (wind) w ww. budynkach. ITB, Oddział Śląski w Katowicach.

Słowik, L. (2016). Prognozowanie wychyleń budynków spowodowanych eksploatacją górniczą. W Obiekty budowlane na terenach górniczych. Diagnozowanie, sposoby wzmocnień i napraw istniejacych konstrukcji. (strony 183-201). Polski Związek Inżynierów i Techników Budownictwa, Oddział w Katowicach. 


\title{
INFLUENCE OF BUILDING DEFLECTION ON THE STRESS OF CONSTRUCTION UNDER MINING CONDITIONS
}

\begin{abstract}
One of the effects of underground mining is the slope of the terrain causing transitory and also under certain mining and geological conditions, permanent deflection of buildings from the vertical. The article discusses the static-strength aspect of tilting of a multi-story building caused by impact of underground mining activity. Deflection of the building from the vertical causes the horizontal load of the construction as a component of the weight of the building. The influence of horizontal forces on the construction of a building is particularly unfavorable for objects of high center of gravity. The work presents an example of numerical simulation, which was aimed at determining.
\end{abstract}

Key words: mining exploitation, tilt of a building, construction modeling 